\title{
Hledač panacey
}

František Všetička

(Olomouc, Česká republika)

Každý básník si ve své poezii vytvoří svůj vlastní svět. Některý se spokojí s domácím teritoriem, jinému nestačí náš svět a sahá po nekonečných dálavách kosmu. Jan Szczurek (ročník 1949) patř́i k prvním, jeho svět je územně i pocitově vymezen. Ve svém debutu Hledání panacey (W poszukiwaniu panaceum) má sice báseň Mezi Biskupskou kupou a Wawelem (Między Kopą Biskupią a Wawelem), ale nemylme se, jeho svět je podstatně užší, nebot' královský Wawel je přece jenom daleko. Śíri jeho vlastního světa vymezuje vstupní odstavec básně Testament:

\author{
$Z$ údolí \\ mezi Horou svaté Anny \\ a Biskupskou kupou \\ potř́sněni inkoustem \\ rytíri slova \\ složí jeho dar \\ jak dobré víno \\ ve sklípku františkánů. \\ ... \\ $Z$ doliny \\ między Góra św. Anny \\ a Kopa Biskupia \\ zbroczeni atramentem \\ rycerze stowa \\ złoża jego dar \\ jak dobre wino \\ w piwnicy Franciszkanów.
}

V básni O Slezsku (O Śłąsku) je sice řeč o Katyni, Tobruku, Narwiku a Monte Cassinu, ale jde jen o výčet - vlastní Szczurkův svět ztělesňuje území mezi Horou svaté Anny a Biskupskou kupou. 
Szczurkovo teritorium je zároveň územím zámků, zámeckých budov a ještě spíše ruin, jež v této části Slezska zůstaly po odchodu německé šlechty. Básník je touto zámeckou kulturou zajat, okouzlen a uhranut. Čím je zámecká ruina ubožejší a poničenější, tím víc jej poutá. Názorným dokladem je jeho vztah k ruinám zámku Dobrá, na jejichž rekonstrukci se aktivně a s nemalým zaujetím podílí. O ruině samotné a o nešţastné hraběnce Marylin White Seherr-Thoss je ve sbírce několik básní. Jedna z nich začíná:

\title{
Z palácových komnat \\ zmizely stromy \\ někdy je slyšet pouze \\ muziku a ptáky. \\ ... \\ Z patacowych komnat \\ zniknęty drzewa \\ niekiedy tylko stychać \\ muzykę i ptaki.
}

I my jsme navštívili zámek v Dobré, museli jsme s jeho ochráncem projít celý zámecký areál a vyšlapat až na věž. Bylo časné jaro, foukal mrazivý vítr, dotírala zima, ale zapálený obnovitel nám vyprávěl o hraběnce Marylin, která, když oknem spatřila přijíždět gestapo, skočila $z$ okna a ukončila tak svou životní pout. Mrazivá historie, nás promrazil zimní vítr, zasvětitel prožíval naopak přicházející vesnu.

Szczurkovo Panaceum zahrnuje také české reálie, které mírí na Broumovsko. Konkrétně do Křinic u Broumova, jež jsou spjaty s poetkou Věrou Kopeckou, organizátorkou česko-polských básnických setkání. Této obci a básniŕce samotné jsou věnovány tři básně, jež naznačují Szczurkovo tíhnutí k českému živlu. Nejkratší z nich, tváŕící se jako haiku, má název Věra (Vera):

\author{
Vrací pamět \\ matiné $z$ Broumova \\ dává ovoce. \\ Powraca pamięć \\ poranek $z$ Broumova \\ daje owoce.
}

Po technické stránce je Szczurek básník obraznosti, v básni Poutník (Pielgrzym) zejména obraznosti vizuální: 
Je takový kraj

kde dokonce hřbitov

zahoř životem mrtvých.

$\cdots$

Jest taki kraj

gdzie nawet cmentarz

zapłonie życiem zmartych.

Jindy se Szczurek projevuje jako poeta inklinující k aforistickému sdělení; např. na začátku básně Být sebou (Sobą być):

\author{
Nenávist tě postihne \\ od těch \\ na jejichž chyby poukazuješ. \\ $\cdots$ \\ Wrogości doświadczysz \\ od tych \\ którym btędy wskazujesz.
}

Obdobně kupř. v básni Hnízda (Gniazda).

Básníkova usedlost v Łączniku na Opolsku leží v rovině, takže je vidět do daleka, při dobrém počasí je prý vidět i jesenický Praděd. Seděli jsme na verandě, bylo hezké počasí a Szczurek nám ukazoval v dálce nejvyšší horu Jeseníků. Já ji neviděl, ani dalekohledem. Jan Szczurek je básník vidoucí, což souvisí s výše zmíněnou vizuálností.

\title{
About the author
}

František Všetička

Olomouc, Czech Republic

fvseticka@seznam.cz

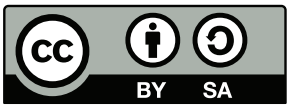

Toto dílo Ize užít v souladu s licenčními podmínkami Creative Commons BY-SA 4.0 International (<https:// creativecommons.org/licenses/by-sa/4.0/legalcode>). Uvedené se nevztahuje na díla či prvky (např. obrazovou či fotografickou dokumentaci), které jsou v díle užity na základě smluvní licence nebo výjimky či omezení príslušných práv. 
